\title{
Anti-adipogenic Effect of Undaria pinnatifida Extracts by Ethanol in 3T3-L1 Adipocytes
}

\author{
HyeJin Kim, Chang-Han Kang and Sung-Koo Kim* \\ Department of Biotechnology, Pukyong National University, Busan 608-737, Korea
}

Received May 28, 2012 /Revised July 2, 2012 / Accepted July 2, 2012

\begin{abstract}
Undaria pinnatifada has been used as a natural diet food with few calories and as a source of iodine. Even though $U$. pinnatifida has been regarded as a diet food, the mechanisms of its inhibitory effects on adipocyte differentiation and the accumulation of fat in adipocytes are poorly understood. In this study, the effect and mechanism of $U$. pinnatifida ethanol extract on 3T3-L1 differentiation into adipocytes were investigated. The effects of $U$. pinnatifida ethanol extract on cell viability and the anti-adipogenic effect were investigated via MTT assay, Oil red O staining, RT-PCR, and western blot. The $U$. pinnatifida ethanol extract did not show toxicity up to a concentration of $50 \mu \mathrm{g} / \mathrm{ml}$. The addition of $U$. pinnatifida ethanol extract decreased triglyceride contents by $40 \%$ when $50 \mu \mathrm{g} / \mathrm{ml}$ of $U$. pinnatifida ethanol extract was added during 3T3-L1 differentiation and adipocyte triglyceride formation. The transcription and expression of peroxisome proliferator-activated receptor y (PPARy), leptin, and hormone-sensitive lipase (HSL) as adipocyte-specific proteins were determined by RT-PCR and western blot. The overexpression of PPARy could accelerate adipocyte differentiation. Also, leptin was secreted for triglyceride accumulation in the adipocytes and the increase of adipocyte cell size. Thus, PPARY and leptin were used as indicators of obesity. PPARY and leptin were repressed by the increased addition of $U$. pinnatifida ethanol extract. This indicates that $U$. pinnatifida was effective as an anti-obesity agent by repressing the differentiation of 3T3-L1 into adipocytes and inhibiting triglyceride formation in adipocytes.
\end{abstract}

Key words : Undaria pinnatifida, 3T3-L1, PPAR $\gamma$, leptin, hormone sensitive lipase (HSL)

\section{서 론}

최근 전 세계 비만인구가 2015년에는 7억 명에 이를 것으로 추산되며, 세계적으로 비만억제에 관한 관심이 증가하고 있 다. 국내에서도 식습관 및 생활습관의 서구화로 인해 비만인 구가 증가하고 있으며, 비만의 효과적인 치료 및 예방법에 대 해 많은 연구가 수행되고 있다 $[13,15,16]$. 비만은 섭취되는 열 량이 소모되는 열량보다 많아 체내에 지방이 과도하게 축적되 어, 제 2형 당뇨병, 심혈관계 질환, 각종 암 및 고지혈증과 같은 성인병의 발병원인으로 간주된다[9,14]. 비만은 지방전구세포 의 분화 및 adipogenesis 과정에 의하여 지방세포의 세포 내 triglyceride 축적으로 발생되며, 이러한 기작을 조절하는 것이 비만 억제의 치료 방법으로 알려져 있다[9]. 항비만 관련 소재 연구나 기작 연구에는 일반적으로 mouse embryo 유래의 지 방전구세포(3T3-L1)를 사용하며, 지방전구세포의 증식, 성숙 지방세포로의 분화 및 성숙지방세포의 증식 과정과 같은 3단 계로 구분된다[4]. 그 중 가장 중요한 성숙지방세포로의 분화 과정에서는 adipogenic signal induction, growth arrest (G1 기), mitotic clonal expansion, re-enter cell cycle의 세부적인

*Corresponding author

Tel : +82-51-629-5868, Fax : +82-51-629-5863

E-mail : skkim@pknu.ac.kr
단계로 진행된다[15]. Adipogenesis 과정은 insulin을 포함한 호르몬 자극과 함께 분화과정에 관여하는 유전자들의 발현에 필요한 전사인자들의 활성이 필수적이며, peroxisome proliferator-activated receptor $\gamma$ (PPAR $\gamma$ )와 같은 adipogenic transcription factor가 중요한 조절인자로서 관여하는 것으로 알려져 있다[15]. PPAR $\gamma$ 는 핵 내 수용체형의 전사인자로 같 은 수용체형 전사인자인 Retinoid X receptor a (RXRa)와 heterodimer를 형성하여 여러 종의 지방산이나 지방산 대사산물 의 내인성 ligand로써 결합하여 전사가 활성화 된다. Leptin은 지방세포의 비만유전자에 의해 생성되는 호르몬으로 시상하 부에 작용하여 음식섭취를 억제시키고 에너지 소비를 증가시 켜 비만을 조절하는 호르몬이다. 지방세포 내 지방 축적량이 높을수록 leptin의 분비량이 증가하는 것으로 알려져 있으며 혈중 leptin의 농도는 체지방량을 나타내는 지표로 비만연구 에 많이 사용되고 있다[6]. Hormone sensitive lipase (HSL)효 소는 지방조직에서 지방을 분해할 때 triglyceride를 유리지방 산과 글리세롤로 분해하는 지방분해효소이며, 지방세포 내 지 방 축적량이 높을수록 발현량이 증가하는 것으로 알려져 있다 [10]. 비만 억제 및 비만과 관련된 대사성 질환의 효과적인 치 료를 위해서는 지방세포 특이적인 분비물질의 조절과 더불어 지방세포 분화과정에 관여하는 전사인자들의 활성을 억제하 는 것이 중요하다고 판단된다. 
해조류는 다양한 생리활성 물질을 가진 자원으로 한국, 일 본 및 중국과 같은 아시아 국가에서는 식품 및 민간요법으로 질병의 치료제로 사용되고 있다[8]. 우리나라 연안에서 많이 양식되고 있는 미역(Undaria pinnatifida)은 갈조류로써 천연카 로티노이드계 색소와 같은 생리활성물질을 함유하고 있으며 [5], 효과적인 식이조절제로서 알려져 있다. 미역 에탄올 추출 물이 동물실험을 통해 지방조직의 증가를 억제시키는 효과가 알려져 있지만 항 비만 효과에 따른 유전자적 단계에서 연구 가 미비한 실정이다.

본 연구에서는 미역 에탄올 추출물의 항비만 효과를 3T3-L1 세포에서 지방세포로의 분화를 촉진시키는 PPAR $\gamma$, 지방세포에서 분비되는 호르몬인 leptin, HSL의 mRNA와 단 백질 발현량을 분석하여, 미역 에탄올 추출물에 의한 3T3-L1 의 분화 유도능 억제에 관한 mRNA 전사 및 단백질 발현에 관한 연구를 수행하였다.

\section{재료 및 방법}

\section{미역 에탄올 추출물의 제조}

본 실험에 사용된 미역은 (주)기장물산에서 제공 받았으며, 건조된 미역은 Hammer mill을 이용하여 잘게 분쇄 하였다. 건조 미역 $100 \mathrm{~g}$ 당 에탄올 11 를 첨가하여 $70^{\circ} \mathrm{C}, 3$ 시간 동안 추출하였다. 미역 에탄올 추출물은 20 분간 $708 \times g$ 로 원심 분 리하여 상등액만 분리하였다. 분리된 상등액을 $0.45 \mu \mathrm{m}$ filter로 여과하여 감압 농축과정과 동결건조를 통해 미역 에탄 올 추출물을 제조하였다. 미역 에탄올 추출물은 $\mathrm{DMSO}$ 에 녹 여 $250 \mathrm{mg} / \mathrm{ml}$ 농도로 만들어 적정한 농도로 희석하여 사용 하였다.

\section{세포 배양 및 시약}

본 실험에 사용된 3T3-L1 지방전구세포는 미국세포은행 (American Type Culture Collection: ATCC, USA)에서 분양 받아 사용하였다. 세포배양은 Dulbecco's Modified Eagle's Medium (DMEM, Gibco BRL, Grand Island, NY, USA)에 $10 \%$ bovine serum (Gibco BRL)과 100 units $/ \mathrm{ml}$ 의 penicillin, $0.1 \mathrm{mg} / \mathrm{ml}$ 의 streptomycin 및 $0.25 \mu \mathrm{g} / \mathrm{ml}$ 의 amphotericin B (Sigma Aldrich, St. Luis, $\mathrm{MO}, \mathrm{USA}$ )을 첨가하여 $37^{\circ} \mathrm{C}, 5 \% \mathrm{CO}_{2}$ 조건에서 배양하였다.

\section{T3-L1 지방전구세포의 분화유도}

3T3-L1 지방전구세포를 6 well plate에서 confluent 상태가 될 때까지 배양한 후 분화배지 I [DMEM, $10 \%$ fetal bovine serum (FBS, Cellgro, Manassas, VA, US), $10 \mu \mathrm{g} / \mathrm{ml}$ Insulin, $0.25 \mu \mathrm{M}$ dexamethasone, $0.5 \mathrm{mM}$ 3-isobuthyl-1-methylxanthin (IBMX, Sigma Aldrich)]을 첨가하여 지방전구세포의 분화를 유도하였다. 2일간의 분화유도 후 dexamethasone과
$\mathrm{IBMX}$ 를 제거한 분화배지 $\Pi$ 로 배지를 교환하여 지방전구세 포의 분화를 촉진하였다. Insulin이 제거된 배지에서 분화가 촉진된 지방세포를 2 일간 배양하여 세포독성과 지방세포분화 및 지방축적의 억제효과를 확인하였다.

\section{세포 독성 확인}

3T3-L1과 지방세포에서 미역 에탄올 추출물의 세포독성은 MTT assay로 분석하였다[1]. 6 well plate에서 confluent 상태 가 될 때까지 배양된 3T3-L1 지방전구세포에 미역 에탄올 추 출물을 $0,10,20,30,40,50,60,80,100 \mu \mathrm{g} / \mathrm{ml}$ 의 농도로 첨가하 여 24시간 배양하였다. Tetrazolium bromide salt (MTT, Sigma Aldrich)를 $300 \mu \mathrm{l}$ 첨가하여 $37^{\circ} \mathrm{C}, 4$ 시간 동안 배양한 후 배양액을 제거하였다. DMSO (Sigma Aldrich)를 $100 \mu \mathrm{l}$ 첨 가하여 생성된 formazan을 녹였다. ELISA reader (EL800, BioTek, Winooski, VT, USA)를 이용하여 $630 \mathrm{~nm}$ 의 흡광도에 서 상대적 세포 생존율을 측정하였다.

\section{Oil Red O 염색}

지방전구세포 분화 시에 형성된 지방의 함량은 Oil Red O staining을 이용하여 측정하였다. 미역 에탄올 추출물은 분화 과정의 각 단계마다 분화배지에 $0,10,20,30,40,50 \mu \mathrm{g} / \mathrm{ml}$ 의 농도로 첨가하였다. 분화과정 8 일째에 성숙지방세포의 배양 액을 제거한 후 $10 \%$ 의 formalin으로 1 시간 동안 지방세포를 고정하였다. $60 \%$ isopropyl alcohol을 이용하여 세척한 후 Oil Red O solution (Sigma Aldrich)을 넣고 실온에서 10분간 염색 하였다. Oil Red O solution을 제거하고 증류수로 4회 세척하 여 완전히 건조하였다. $100 \%$ isopropyl alcohol을 사용하여 염색된 지방을 추출하였으며, ELISA reader를 이용하여 490 $\mathrm{nm}$ 의 흡광도에서 지방함량을 분석하였다.

\section{단백질 추출 및 Western blot}

단백질을 추출하기 위해 Radioimmunoprecipitation assay (RIPA) buffer [150 mM NaCl, 1.0\% Triton X-100, 0.5\% Sodium deoxycholate, $0.1 \%$ Sodium dodecyl sulfate (SDS), $50 \mathrm{mM}$ Tris ( $\mathrm{pH}$ 8.0)]를 지방세포에 첨가하였다. $4^{\circ} \mathrm{C}$ 에서 30 분 간 반응시킨 후 $14,240 \times \mathrm{g}$ 에 20 분간 상등액을 원심 분리하였 다. 상등액의 총 단백질량은 Bicinchoninic acid (BCA) method 에 따라 Bio-Rad protein assay (Bio-Rad, Hercules, CA, USA) 을 사용하여 정량하였다. 동량의 단백질을 $12 \% \mathrm{SDS}$ - polyacrylamide gel에서 전기영동 하였으며, 전기 영동 후 gel 내의 단백질을 Nitrocellulose membrane (PALL, Washington, NY, $\mathrm{USA}$ )으로 $100 \mathrm{~V}$ 에서 1시간 동안 전사시켰다. Tris-buffered saline (TBS) [0.02 M Tris- $\mathrm{HCl}, 0.5 \mathrm{M} \mathrm{NaCl}, \mathrm{pH}$ 7.5]에 3\% bovine serum albumin을 첨가한 blocking solution을 사용하 여 실온에서 2시간동안 blocking을 실시하였다. Blocking한 membrane을 10분 동안 3회 Tris-buffered saline with 
tween-20 (TTBS) [0.02 M Tris-HCl, $0.5 \mathrm{M} \mathrm{NaCl}, 0.05 \%$ Tween-20, $\mathrm{pH}$ 7.5]로 세척한 후 $1 \% \mathrm{BSA}$ 를 포함한 TTBS에 1:1,000으로 희석시킨 1차 항체를 실온에서 2시간 동안 반응시 켰다. TTBS로 3 회 세척한 후, $1 \% \mathrm{BSA}$ 를 포함한 TTBS에 1:1,000으로 희석시킨 2차 항체를 실온에서 2시간 동안 반응시 켰다. 2차 항체가 부착된 membrane은 TTBS로 세척하였고, 2차항체와 결합한 단백질은 5-bromo-4-chloro-3-indolyl phosphate/nitro blue tetrazolium (BCIP/NBT, Sigma Aldrich)로 발색시켰다.

\section{Real-Time PCR에 의한 mRNA의 분석}

미역 에탄올 추출물을 첨가하여 분화시킨 지방세포의 Total RNA는 Ribospin ${ }^{\mathrm{TM}}$ kit (GeneAll, Seoul, Korea)를 사용하여 분리하였다. 분리된 RNA를 각각의 primer, DEPC water와 Takara (Dalian, Japan)의 One step SYBR PrimeScript ${ }^{\mathrm{TM}}$ RT-PCR Kit를 넣고 Real-Time PCR Detection System (Bio-Rad)을 이용하여 증폭하였다. RT-PCR에 사용된 Primer 의 서열은 Table 1 에 나타내었으며, $\beta$-actin 유전자는 internal control로 사용하였다. 첫 번째 단계에서 반응 조건은 $42^{\circ} \mathrm{C}$, 5 분, $95^{\circ} \mathrm{C}$ 에서 10 초간 반응 시키고, 두 번째 단계의 반응 조건 은 $95^{\circ} \mathrm{C}, 5$ 초, $60^{\circ} \mathrm{C}$ 에서 20 초 간격으로 cycle을 35 번 반복하여 수행하였다. 결과 분석법으로는 $2^{-(\triangle \Delta \mathrm{CT})} \operatorname{method}$ 를 이용하였 으며[7], mRNA의 상대적 발현량은 control에 대한 sample의 상대적 유전자 발현 값으로 나타내었다.

\section{결과 및 고찰}

미역 에탄올 추출물이 성숙한 지방세포의 생존율에 미치는 영향

미역 에탄올 추출물 처리에 따른 3T3-L1 세포 및 성숙지방 세포에서의 생존율을 알기 위하여 MTT assay를 실시하였다. Fig. 1에 나타난 바와 같이 지방전구 세포인 3T3-L1세포와 성 숙지방세포에서 모두 $50 \mathrm{\mu g} / \mathrm{ml}$ 의 농도 까지는 세포의 생존율 에 영향을 미치지 않았지만 $60 \mathrm{\mu g} / \mathrm{ml}$ 이상의 농도부터는 생존 율이 급격히 감소하였으며, $100 \mu \mathrm{g} / \mathrm{ml}$ 에서는 약 $40 \%$ 의 생존 율을 나타내었다. 그 결과, 지방전구 세포인 3T3-L1 세포와
지방세포에서 생존율에 영향을 미치지 않는 $50 \mathrm{\mu g} / \mathrm{ml}$ 의 농도 까지를 실험 조건으로 설정하였다.

\section{미역 에탄올 추출물이 지방세포에서 triglyceride 축적에} 미치는 영향

미역 에탄올 추출물이 지방세포의 분화 및 triglyceride 축 적에 미치는 영향을 확인하기 위하여 3T3-L1 세포를 성숙지방 세포로 유도하여 0 50 $\mathrm{\mu g} / \mathrm{ml}$ 의 농도로 미역의 에탄올 추출물 을 첨가하였다. 분화 유도 8 일째, 분화가 완료된 성숙지방세포 에 Oil red O 염색을 하였으며, 염색된 lipid droplet을 isopropanol로 추출한 후 ELISA reader를 이용하여 triglyceride 함량을 분석하였다. Fig. 2에 나타난 바와 같이 정상배지에서 분화된 지방세포와 비교해 볼 때, 미역 에탄올 추출물을 첨가 한 배지에서 지방세포 내 축적된 triglyceride 함량이 감소하였 다. $50 \mu \mathrm{g} / \mathrm{ml}$ 의 미역 에탄올 추출물 농도에서 지방 축적이 약 $40 \%$ 로 감소되었으며, 미역 에탄올 추출물에 의한 trigly-

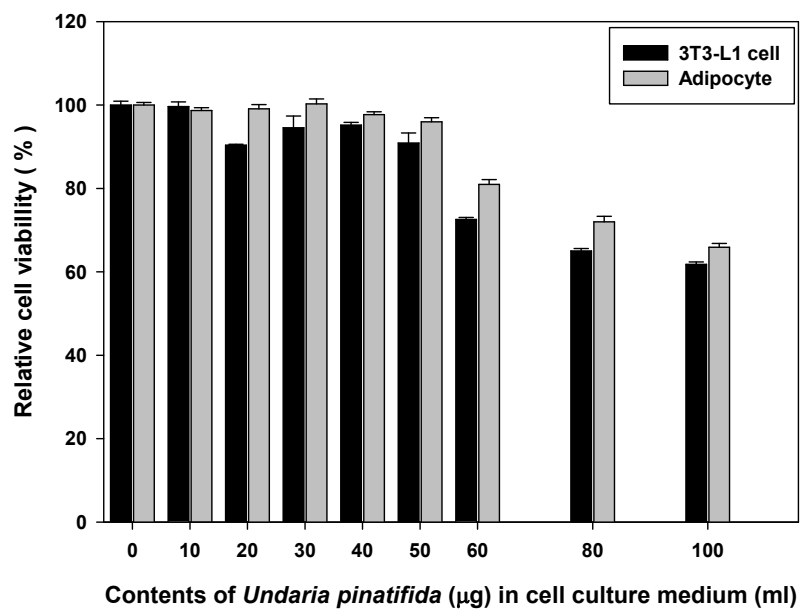

Fig. 1. Effect of $U$. pinnatifida ethanol extracts on cell viability in 3T3-L1 and adipocyte. Cells were incubated for $24 \mathrm{hr}$ in cell culture medium with various concentrations of extract. Cell viability was determined by MTT assay. Values are expressed as percentage of the viability of control. Data were expressed as relative cell viability \pm S.D. of triplicate trials.

Table 1. Sequences of oligonucleotide primers used for real-time PCR

\begin{tabular}{ll}
\hline Gene Names & Sequences \\
\hline PPAR $\gamma$ & F: 5'-GAG-ATG-CCA-TTC-TGG-CCC-ACC-AAC-TTC-GG-3' \\
& R: 5'-TAT-CAT-AAA-TAA-GCT-TCA-ATC-GGA-TGG-TTC-3' \\
Leptin & F: 5'-GGA-TCA-GGT-TTT-GTG-GTG-CT-3' \\
& R: 5'-TTG-TGG-CCC-ATA-AAG-TCC-TC-3' \\
HSL & F: 5'-ACC-GAG-ACA-GGC-CTC-AGT-GTG-3' \\
& R: 5'-TCCCTCTCAGCTGTGGTGGTGAA-3' \\
\multirow{3}{*}{-actin } & F: 5'-AGC-CAT-GTA-CGT-AGC-CAT-CC-3' \\
& R: 5'-TCC-CTC-TCA-GCT-GTG-GTG-GTG-AA-3' \\
\hline
\end{tabular}




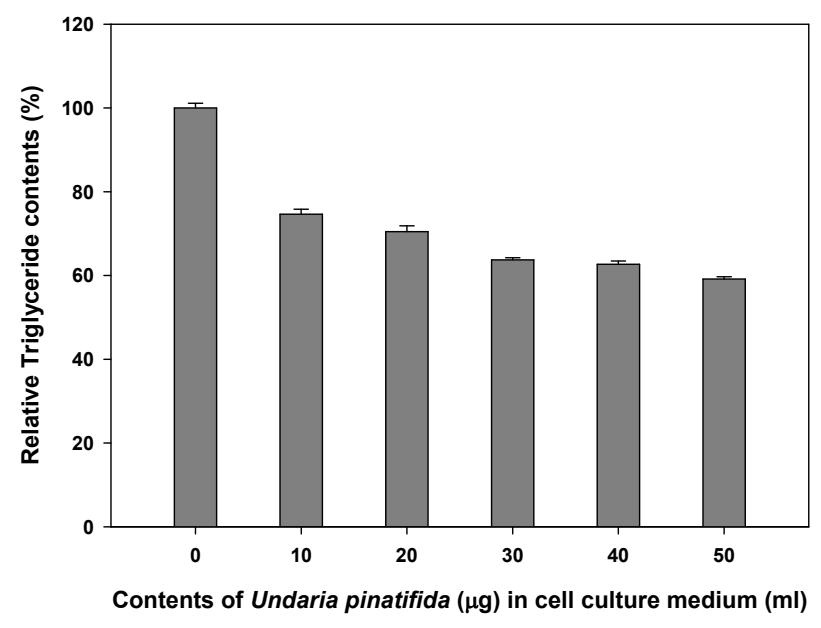

Fig. 2. Inhibitory effect of $U$. pinnatifica ethanol extract on triglyceride contents in adipocyte. 3T3-L1 cells were cultured in differentiation medium I and II with $U$. pinnatifida ethanol extract during adipocyte differentiation. The intercellular triglyceride contents of adipocytes were determined by $\mathrm{Oil}$ red $\mathrm{O}$ staining. The relative triglyceride contents were measured at $\lambda=490 \mathrm{~nm}$ by ELISA reader. Values are expressed as the means \pm S.D.

ceride 축적 억제효과를 확인할 수 있었다.

미역의 에탄올 추출물이 지방세포 분화 조절인자들의 발현 에 미치는 영향

지방전구세포로부터 지방세포로의 분화는 많은 종류의 adipogenic transcription factor들의 조절에 의하여 유발되는 것으로 알려져 있다[11]. PPAR $\gamma$ 는 지방전구세포에서 지방세 포로의 분화를 촉진시키며, PPAR $\gamma$ 의 발현량 증가는 지방세 포의 증가를 의미한다[20]. Leptin과 HSL은 지방세포에서 특 이적으로 분비되는 호르몬과 효소로 지방세포 증가에 관한 지표로 사용된다[6,10]. 이렇게 분화된 세포는 lipid droplet 생 성 및 세포의 크기 증가 등 형태학적인 특징과 더불어 특이적 인 유전자의 발현을 유발함으로서 지방 세포의 특징을 지니게 된다. 따라서 미역의 에탄올 추출물이 PPAR $\gamma$, leptin과 HSL 의 발현에 어떠한 영향을 미치는지 western blot과 RT-PCR을 이용하여 mRNA 및 단백질 단계에서 확인하였다. Fig. 3(A)와 (B)에 나타난 바와 같이, 분화유도 과정에서 미역 에탄올 추출 물을 처리한 경우 HSL의 발현은 mRNA와 단백질 수준에서 유의적인 차이가 없었다. 그러나 PPAR $\gamma$ 와 leptin의 발현은 미역 에탄올 추출물의 농도가 증가함에 따라 감소하였다. 이 와 같은 결과는 미역 에탄올 추출물 처리에 의해 $\operatorname{PPAR} \gamma$ 의 발현이 저해되며 이로 인해 지방세포분화, 지방축적 및 leptin 의 발현이 저해되는 것으로 판단된다.

본 연구에서는 미역 에탄올 추출물의 항 비만 효과를 유전 자적 단계에서 $\operatorname{PPAR} \gamma$, leptin과 HSL을 통해 3T3-L1의 분화 유도능 억제에 관한 mRNA 전사 및 단백질 발현에 관한 연구
(A)

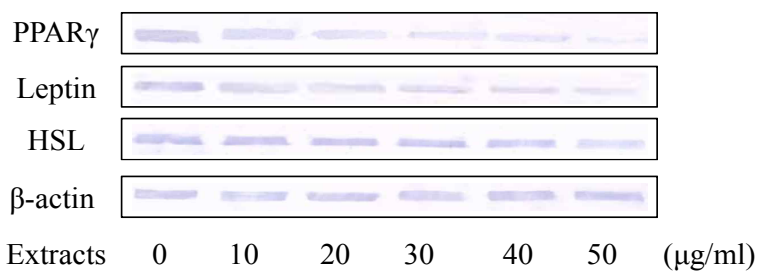

(B)

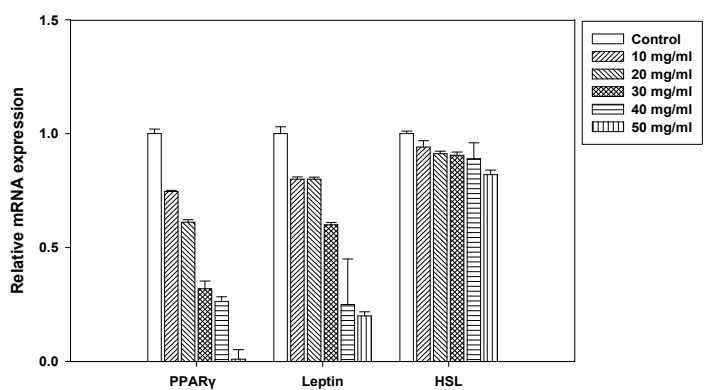

Fig. 3. Effects of $U$. pinnatifida ethanol extracts on PPARy, Leptin and HSL in adipocytes determined by western blot (A) and RT- PCR (B) analysis. 3T3-L1 cell in media with different concentrations of $U$. pinnatifida ethanol extracts were differentiated into adipocytes for 8 days. $\beta$-actin was used as an internal control. Values are expressed as mean \pm S.D.

를 수행하였으며, 그 결과 미역 에탄올 추출물이 지방세포의 감소와 지방축적에 영향을 미쳐 결과적으로 지방세포의 수와 세포 내 triglyceride의 함량이 감소되는 것으로 사료된다.

\section{감사의 글}

본 연구는 국토해양부 소관 해양생명공학기술개발사업의 연구비 지원에 의해 수행되었습니다.

\section{References}

1. Cole, S. P. 1986. Rapid chemosensitivity testing of human lung tumor cells using the MTT assay. Cancer Chemother. Pharmacol. 17, 259-263.

2. Frayn, K. N., Coppack, S. W., Fielding, B. A. and Humphreys, S. M. 1995. Coordinated regulation of hormone-sensitive lipase and lipoprotein lipase in human adipose tissue in vivo implications for the control of fat storage and fat mobilization. Adv. Enzyme Regul. 35, 163-178.

3. Gesta, S., Tseng, Y. H. and Kahn, C. R. 2007. Developmental origin of fat: tracking obesity to its source. Cell 131, 242-256.

4. Green, H. and Kehinde, O. 1974. Sublines of mouse 3T3-L1 cells that accumulate lipid. Cell 131, 242-256

5. Kotake, N. E., Kushiro, M., Zhang, H., Sugawara, T. and Miyashita, K. 2001. Carotenoids affect proliferation of hu- 
man prostate cancer cells. J. Nutrition 131, 3301-3306.

6. Leroy, P., Dessolin, S., Villageois, P., Moon, B. C., Friedman, J. M., Ailhaud, G. and Dani, C. 1996. Expression of ob gene in adipose cells regulation by insulin. J. Biol. Chem 271, 2365-2368

7. Livak, K. J. and Schmittgen, T. D. 2001. Analysis of relative gene expression data using real-time quantitative PCR and the 2-[Delta][Delta] CT method. Methods 25, 402-408.

8. Muhammad, S. Ali., Muhammad, J., Muhammad, S., Muhammad, K. P., Shaista, H. and Viqar, U. A. 2000. Metabolites of marine algae collected from karachi - coasts of arabian Sea. J. Nat. Prod 6, 61-65.

9. Peter, G. K. 2000. Obesity as a medical problem. Nature 404, 635-643.

10. Robert, Z., Juliane, G. S., Guenter, H., Gabriele, S., Ruth, B. G., Monika, R., Achim, L., Georg, N., Frank, E., Albin, H. and Rudolf, Z. 2004. Fat mobilization in adipose tissue is promoted by adipose triglyceride lipase. Science 306, 1383-1386.
11. Rosen, E. D., Walkey, C. J., Puigserver, P. and Spiegelman, B. M. 2000. Transcriptional regulation of adipogenesis. Gene Dev. 14, 1293-1307.

12. Schoonjans, K., Staels, B. and Auwerx, J. 1996. The peroxisome proliferator activated receptors (PPARS) and their effects on lipid metabolism and adipocyte differentiation. Biochim Biophys. Acta. 1302, 93-109.

13. Scott, M. G. 2004. Obesity, metabolic syndrome, and cardiovascular disease. J. Clin. Endocrinol Metab. 89, 2595-2600.

14. Spiegelman, B.M. 2001. Obesity and the regulation of energy balance. Cell 104, 531-543.

15. Wellman, N. S. 2002. Causes and consequences of adult obesity: health, social and economic impacts in the united States. Asia Pac. J. Clin. Nutr. 11, S705-S709.

16. Wyatt, S. B., Winters, K. P. and Dubbert, P. M. 2006. Overweight and obesity: prevalence, consequences, and causes of a growing public health problem. Am J. Med Sci. $331,166-174$.

\section{초록 : 미역 에탄올 추출물이 지방세포 형성과정에 미치는 영향}

김혜진 · 강창한 · 김성구*

(부경대학교 수산과학대학 생물공학과)

미역(Undaria pinnatifada)은 낮은 칼로리 및 요오드의 원료로써 천연체중조절식품으로 알려져 있다. 미역이 체 중조절식품으로 알려져 있음에도 불구하고, 지방세포 분화 및 지방축적에 관한 저해 기작은 연구가 미비하다. 본 연구에서는 3T3-L1에서 지방세포로 분화가 일어나는 단계에서 미역에탄올추출물의 효과 및 기작을 확인하였 다. 미역에탄올추출물의 독성과 지방축적저해효과는 MTT assay, Oil red O staining, RT-PCR과 western blot으 로 분석하였다. 미역에탄올추출물은 $50 \mathrm{\mu g} / \mathrm{ml}$ 의 농도에서 독성을 띄지 않았다. 3T3-L1의 분화 및 지방세포에서 triglyceride축적과정동안 $50 \mu \mathrm{g} / \mathrm{ml}$ 의 미역에탄올추출물을 처리하였으며, 미역에탄올추출물은 지방세포에서 triglyceride의 축적을 $40 \%$ 감소시켰다. 지방세포 특이적 단백질인 Peroxisome proliferator activated receptor $\gamma$ (PPAR $\gamma$ ), leptin과 Hormone sensitive lipase (HSL)의 발현은 RT-PCR과 western blot으로 확인하였다. PPAR $\gamma$ 의 과발현은 지방세포의 분화를 촉진시킨다. 또한 지방세포 크기의 증가와 세포 내 triglyceride의 함량에 따라 leptin은 세포 외로 분비된다. 그러므로 PPAR $\gamma$ 와 leptin은 비만의 지표로 사용된다. 첨가한 미역에탄올추출물 의 농도가 높아질수록 PPAR $\gamma$ 와 leptin의 발현이 억제되었다. 이상의 결과를 통하여, 미역의 에탄올 추출물은 지방전구세포의 분화를 억제시키며, 지방세포 내 triglyceride의 축적을 저해하는 것으로 판단된다. 